\title{
Pemanfaatan Instagram bagi Pengembangan Pemasaran Usaha Mikro Kecil dan Menengah di Banjarbaru
}

\author{
Sudirwo $^{1}$, Arifia Nurriqli ${ }^{2}$, Muhammad Risanta $^{3}$ \\ ${ }^{1,2,3}$ Sekolah Tinggi Ilmu Ekonomi Pancasetia Banjarmasin \\ Email : sudirwo@gmail.com
}

\begin{abstract}
Many micro, small and medium enterprises (MSMEs) still sell products conventionally and few have used e-commerce. So that not all products from MSMEs are widely known by the public. Al-Firdaus Borneo is a MSME player engaged in woven handicrafts made from purun plants which has been running for about two years in utilizing Instagram social media with an account @ pengrajinanyamanpurunalfirdaus. The method used in this research is descriptive qualitative, in which the researcher tries to describe and analyze specifically the data obtained in the field in accordance with the focus of the problem to be studied. Information and data obtained by researchers through interviews with craftsmen as well as account owners who are the object of research and through observations made during the research activities in progress. Based on this research, it was found that the use of Instagram social media had a positive impact on the development of Al Firdaus product marketing so that Instagram followers and sales increased. In addition, the operation is easy and has many users so that it becomes a practical promotional media, which is cheap, reliable and can reach all users everywhere. However, there are still some obstacles and weaknesses encountered, namely poor internet access in the account owner area, lack of expertise of the account owner in making good and attractive designs, and product prices are not raised so they have to communicate through the contacts provided.
\end{abstract}

Keywords : social media, Instagram, marketing, e-commerce, MSME

Abstrak

Banyak usaha mikro, kecil dan menengah (UMKM) masih menjual produk secara konvensional dan sedikit yang telah menggunakan perdagangan elektronik (e-commerce). Sehingga tidak semua produk-produk dari UMKM dikenal luas oleh masyarakat. Al-Firdaus adalah pelaku UMKM yang bergerak dalam kerajinan anyaman berbahan dasar dari tanaman purun telah berjalan sekitar dua tahun dalam memanfaatkan media sosial Instagram dengan akun @pengrajinanyamanpurunalfirdaus. Metode yang digunakan dalam penelitian ini adalah deskriptif kualitatif, dimana peneliti berusaha untuk menggambarkan dan menganalisis secara spesifik data yang diperoleh di lapangan sesuai dengan fokus masalah yang ingin diteliti. Informasi dan data diperoleh peneliti melalui wawancara terhadap pengrajin sekaligus pemilik akun yang menjadi objek penelitian serta melalui observasi yang dilakukan selama kegiatan penelitian berlangsung. Berdasarkan penelitian ini ditemukan bahwa pemanfaatan media sosial Instagram mempunyai dampak positif bagi pengembangan pemasaran produk Al Firdaus sehingga pengikut Instagram dan penjualan meningkat. Selain itu juga, pengoperasiannya yang mudah dan banyak penggunanya sehingga menjadi media promosi praktis, yang murah, handal dan dapat menjangkau seluruh pengguna di mana saja berada. Namun demikian, masih ada beberapa kendala dan kelemahan yang ditemui yaitu akses internet yang kurang baik di wilayah pemilik akun, kurangnya keahlian pemilik akun dalam membuat desain yang bagus dan menarik, serta tidak dimunculkan harga produk sehingga harus berkomunikasi melalui kontak yang disediakan.

Kata Kunci : media sosial, Instagram, pemasaran, perdagangan elektronik, UMKM

\section{PENDAHULUAN}

Pesatnya perkembangan dunia teknologi dan informasi saat ini, menjadikan internet sebagai alat komunikasi yang banyak diminati oleh masyarakat. Hal ini yang melatarbelakangi perubahan komunikasi konvensional menjadi serba digital dan modern. Sejalan dengan cepatnya perkembangan bidang teknologi, perusahaan maupun pelaku usaha makin dipacu untuk menggunakan teknologi yang maju sebagai senjata untuk tetap bertahan (survive) dan memenangkan persaingan yang kian ketat. Pada akhirnya saat ini penggunaan internet yang menjurus kepada ruang maya (cyberspace) kelihatannya akan mendominasi seluruh kegiatan di masa kini dan masa datang dan secara umum akan 
berubah menjadi alat untuk persaingan antara perusahaan yang satu dengan yang lainnya. Ini pun akan membawa dampak yang sangat besar bagi setiap perusahaan. Dampak pada aspek persaingan adalah terbentuknya tingkat kompetisi yang semakin tajam. Sehingga perusahaan harus memiliki kemampuan yang cepat untuk beradaptasi terhadap perubahan yang terjadi sehingga perusahaan akan mampu bersaing dengan para kompetitornya.

Penggunaan teknologi diharapkan dapat memberikan manfaat yang besar terhadap dunia bisnis yang kompetitif. Perusahaan yang mampu bersaing dalam kompetisi tersebut adalah perusahaan yang mampu mengimplementasikan teknologi ke dalam perusahaannya. Salah satu jenis implementasi teknologi dalam hal meningkatkan persaingan bisnis dan penjualan produk-produk adalah dengan menggunakan perdagangan elektronik (e-commerce) untuk memasarkan berbagai macam produk atau jasa, baik dalam bentuk fisik maupun digital. Dalam penggunaan teknologi tersebut, berbagai pihak yang terkait dengan perusahaan seperti investor, konsumen, pemerintah akan ikut berperan.

Banyak usaha mikro, kecil dan menengah (UMKM) masih menjual produk secara konvensional dan sedikit yang telah menggunakan perdagangan elektronik (e-commerce). Khususnya bagi pengrajin anyaman purun di kampung Palam Banjarbaru yng berjumlah lebih 50 orang. Sehingga tidak semua produk-produk dari UMKM dikenal luas oleh masyarakat. Salah satu faktor penting yang akan menentukan pengembangan pemasaran UMKM adalah melalui media sosial. Pemanfaatan media sosial Instagram diantaranya untuk meningkatkan transformasi usaha melalui kecepatan, ketepatan dan efisiensi informasi dengan jangkauan luas.

Al-Firdaus Borneo adalah pelaku UMKM yang bergerak dalam kerajinan anyaman berbahan dasar dari tanaman purun yang berdomisili di kota Banjarbaru. Dalam mengembangkan pemasaran produknya yang selama ini dilakukan secara konvensioanl, Al Firdaus harus mempunyai strategi yang berbeda dalam memanfaatkan media sosial sebagai media pemasaran berbasis online, yaitu dengan memiliki aplikasi Instagram dengan akun @ pengrajinanyamanpurunalfirdaus. Target pasar dari Al Firdaus adalah semua pengguna Instagram baik di dalam maupun di luar kota Banjarbaru.

Selama ini pelanggan yang ingin membeli suatu produk diharuskan untuk mendatangi tempat dari penjual produk sendiri dan hal itu sangatlah tidak efisien bagi para pelanggan yang mempunyai kesibukan-kesibukan yang sangat padat sekali.
Dengan adanya layanan perdagangan secara elektronik (e-commerce) ini maka pelanggan dapat mengakses serta melakukan pesanan dari berbagai tempat. Dengan adanya era teknologi yang canggih saat ini para pelanggan yang ingin melihat produk yang dipasarkan pengrajin, tidak harus berada di suatu tempat, hal itu dikarenakan saat ini mudah diakses dari mana saja. Aktivitas Al Firdaus di Instagram memudahkan konsumen dalam memilih dan mencari informasi yang lebih spesifik tentang produk yang sedang dicari saat ini, desain terbaru, berkomunikasi dengan pengrajin dan sebagainya.

Berdasarkan latar belakang, maka rumusan masalah adalah bagaimana Pemanfaatan Instagram bagi Pengembangan Pemasaran UMKM di Banjarbaru (pada Pengrajin Anyaman Purun Al Firdaus).

\section{KAJIAN LITERATUR}

Media sosial adalah sebuah media online, dengan para penggunanya bisa dengan mudah berpartisipasi, berbagi, dan menciptakan isi meliputi blog, jejaring sosial, wiki, forum dan dunia virtual. Blog, jejaring sosial dan wiki merupakan bentuk media sosial yang paling umum digunakan oleh masyarakat di seluruh dunia. Menurut Kaplan dan Haenlein (2010), media sosial adalah sekelompok aplikasi berbasiskan internet yang dibangun berdasarkan kerangka pikiran ideologi dan teknologi dari Web 2.0, dan memungkinkan terbentuknya kreasi pertukaran isi informasi dari pengguna internet. Web 2.0 adalah dasar terbentuknya sosial media (Carlson, 2010).

Media sosial mempunyai ciri-ciri, yaitu sebagai berikut :

a. Pesan yang disampaikan tidak hanya untuk satu orang saja namun bisa ke berbagai banyak orang contohnya pesan melalui SMS ataupun internet.

b. Pesan yang disampaikan bebas, tanpa harus melalui suatu Gatekeeper.

c. Pesan yang disampaikan cenderung lebih cepat dibanding media lainnya.

d. Penerima pesan yang menentukan waktu interaksi.

Media sosial merupakan alat promosi bisnis yang efektif karena dapat diakses oleh siapa saja, sehingga jaringan promosi bisa lebih luas. Media sosial menjadi bagian yang sangat diperlukan oleh pemasaran bagi banyak perusahaan dan merupakan salah satu cara terbaik untuk menjangkau pelanggan dan klien. Media sosial seperti blog, facebook, Instagram, twitter, dan youtube memiliki sejumlah manfaat bagi perusahaan dan lebih cepat dari media konvensional seperti media cetak dan 
iklan TV, brosur dan selebaran.

Instagram adalah sebuah aplikasi untuk berbagi foto yang memungkinkan pengguna mengambil foto, menerapkan filter digital, dan membagikannya ke berbagai layanan jejaring sosial, termasuk milik Instagram sendiri. Aplikasi ini diciptakan oleh Burbn, Inc., yang merupakan sebuah perusahaan berbasis teknologi startup dan hanya berfokus pada pengembangan aplikasi untuk telepon genggam.

Instagram merupakan salah satu media jejaring sosial yang dapat dimanfaatkan sebagai media pemasaran. Melalui Instagram produk barang/jasa ditawarkan dengan meng-upload foto atau video singkat, sehingga para calon konsumen dapat melihat jenis-jenis barang/jasa yang ditawarkan (Rahmawati, 2016 : 32).

Perdagangan elektronik (e-commerce) merupakan konsep baru yang bias digambarkan sebagai proses jual beli barang atau jasa pada World Wide Web Internet (Shim, Quershi, Siegel, Siegel, 2000 dalam buku M. Suyanto, 11, 2003) atau proses jual beli atau pertukaran produk, jasa dan informasi melalui jaringan informasi termasuk internet (Turban, Lee, King, Chung, 2000 dalam buku M. Suyanto, 11, 2003).

Sedangkan menurut Kalakota dan Whinston (1997) dalam buku M. Suyanto (2003) mendefinisikan e-commerce dari beberapa perspektif berikut :

a. Perspektif Komunikasi: e-commerce merupakan pengiriman informasi, produk/layanan, atau pembayaran melalui lini telepon, jaringan komputer atau sarana eletronik lainnya.

b. Perspektif Proses Bisnis: e-commerce merupakan aplikasi teknologi menuju otomasi transaksi dan aliran kerja perusahaan.

c. Perspektif Layanan: e-commerce merupakan salah satu alat yang memenuhi keinginan perusahaan, konsumen dan manajemen dalam memangkas service cost ketika meningkatkan mutu barang dan kecepatan pelayanan.

d. Perspektif Online: e-commerce berkaitan dengan kapasitas jual beli produk dan informasi di internet dan jasa online lainnya.

Manfaat yang dapat diperoleh dari ecommerce bagi organisasi menurut M. Suyanto adalah :

a. Memperluas market place hingga ke pasar nasional dan internasional.

b. Menurunkan biaya pembuatan, pemrosesan, pendistribusian, penyimpanan dan pencarian informasi yang menggunakan kertas.

c. Memungkinkan pengurangan inventory dan overhead dengan menyederhanakan supply chain dan management tipe "pull". d. Mengurangi waktu antara outlay modal dan penerimaan produk dan jasa.

e. Mendukung upaya-upaya business process reengineering.

f. Memperkecil biaya telekomunikasi dan internet lebih murah dibanding VAN.

g. Akses informasi lebih cepat.

Selain mempunyai manfaat bagi perusahaan, menurut M. Suyanto e-commerce juga mempunyai manfaat bagi konsumen, yaitu :

a. Memungkinkan pelanggan untuk berbelanja atau melakukan transaksi selama 24 jam sehari sepanjang tahun dari hampir setiap lokasi dengan menggunakan fasilitas internet.

b. Memberikan lebih banyak pilihan kepada pelanggan.

c. Pengiriman menjadi sangat cepat.

Terdapat beberapa alasan mengapa

perusahaan menjalankan bisnis dengan

menggunakan fasilitas e-commerce (Morissan, 2010:335-337), yaitu :

1. Dapat menjangkau audien di seluruh dunia.

2. Dapat melakukan komunikasi interaktif dengan biaya yang efisien.

3. Dapat menjangkau target konsumen tertentu.

4. Lebih mudah menyampaikan perubahan informasi seperti perubahan harga atau informasi lainnya.

5. Meningkatkan pelayanan kepada pelanggan karena tersedia akses selama 24 jam, tujuh hari seminggu.

6. Mendapatkan umpan balik segera dari konsumen.

7. Merupakan saluran distribusi alternatif.

8. Menyediakan biaya penyebaran informasi merek yang efektif dan efisien.

Usaha Mikro Kecil Menengah (UMKM) adalah kelompok usaha terbesar di Indonesia bahkan mungkin di dunia (Agus, 2003). Pada tahun 2001, UMKM memberikan andil $99 \%$ dalam jumlah badan usaha dan 99,6\% dalam penyerapan tenaga kerja. Banyaknya UMKM ini tentu disebabkan karena produk-produk dari UMKM sangat diminati bahkan dibutuhkan oleh masyarakat. Namun demikian tidak semua produkproduk dari UMKM dikenal luas oleh masyarakat. Hal ini disebabkan karena promosi yang dilakukan oleh UMKM kalah gencar dengan promosi dari industri yang lebih besar. Penyebab utama dari hal ini adalah minimnya anggaran promosi dari UMKM.

UMKM berpeluang besar untuk menembus pasar global dan tumbuh menjadi sebuah usaha besar jika dapat memanfaatkan teknologi. UMKM dapat memanfaatkan media promosi periklanan (advertising), pemasaran langsung (direct 
marketing), promosi penjualan (sales promotion), hubungan masyarakat (public relation), dan penjualan perseorangan (personal selling) sebagai sarana promosi manual yang kerap diterapkan. Promosi membutuhkan modal yang tidak sedikit, namun begitu UMKM dapat memanfaatkan kemajuan teknologi di bidang informasi sebagai sarana promosi yang murah, mendunia, dan populer.

Pengrajin adalah seorang yang memiliki jiwa seni kemudian menjadikannya sebagai pekerjaan dalam membuat barang-barang kerajinan atau seseorang yang memiliki keterampilan berkaitan dengan kerajinan tertentu. Kerajinan tangan adalah barang atau benda yang tidak dibuat dengan mesin, tetapi dengan tangan sehingga sering disebut barang kerajinan tangan (handicraft). Berbagai macam contoh hasil kerajinan tangan yang dihasilkan oleh pengrajin maupun kelompoknya misalkan tas, bakul, dompet, tikar, dan lain sebagainya.

Purun merupakan jenis tumbuhan rumput yang hidup liar di dekat air atau rawa. Purun juga sering dikatakan sebagai tumbuhan yang sejenis dengan daun pandan yang hidup di sekitar rawa.

\section{METODE PENELITIAN}

Obyek penelitian ini adalah Toko Pengrajin Anyaman Purun Al Firdaus, Jalan Purnawirawan RT 04, Kelurahan Palam, Kecamatan Cempaka, Kota Banjarbaru, Provinsi Kalimantan Selatan, yang memiliki akun Instagram dengan dengan nama:

http://www.instagram.com/pengrajinanyamanpurun alfirdaus

Metode penelitian yang digunakan peneliti adalah pendekatan kualitatif. Penelitian kualitatif bertujuan untuk menjelaskan fenomena dengan sedalam-dalamnya melalui pengumpulan data sedalam-dalamnya. Menurut Jalaludin Rakhmat (2000:35) penelusuran deskriptif tidak menguji hipotesis atau membuat prediksi, penelitian deskriptif ditujukan untuk (1) mengumpulkan informasi aktual secara rinci yang melukiskan gejala yang ada; (2) mendeskripsikan masalah atau memeriksa kondisi-kondisi dan praktik-praktik yang berlaku; (3) membuat evaluasi.

Adapun data yang digunakan dalam penelitian ini adalah berupa data primer yaitu yang bersumber langsung dari informan yang dilakukan peneliti terjun di lapangan dengan melakukan wawancara pengrajin purun dan administrator yaitu pemegang akun@pengrajinanyamanpurunalfirdaus serta tampilan di Instragram. Sedangkan data sekunder diambil dari dokumen-dokumen yang yang terkait dengan laporan transaksi toko dan pengrajin serta buku-buku referensi dan artikel-artikel yang terkait dengan penelitian ini.

Adapun informan yang digunakan sebagai objek informasi dari penelitian ini yaitu Mufidah, administrator Al Firdaus, toko kerajinan anyaman purun Al Firdaus.

Teknik pengumpulan data untuk menghimpun dan mendapatkan semua data yang diperlukan dalam penelitian ini sebagai berikut:

a. Wawancara

Metode pengumpulan data dengan cara mengadakan tanya jawab yang dilakukan secara langsung kepada para pengrajin kerajinan tangan yang ingin memasarkan jualannya dan para calon pembeli.

b. Observasi

Pengumpulan data melalui pengamatan yang berkaitan dengan objek penelitian. Pengamatan dilakukan langsung secara observasi terhadap akun e-commerce yang sudah ada.

c. Studi Pustaka

Pengumpulan data dengan membaca serta mempelajari dokumen-dokumen, literatur, jurnal, dan buku-buku serta sumber lainnya misalkan internet yang berhubungan dengan e-commerce.

Teknik Analisis Data penelitian ini merupakan penelitian dengan bentuk studi kasus tunggal terpancang. Afriani (2012) Studi Kasus Terpancang adalah penelitian dimana penelitian tersebut terarah pada satu karakteristik. Artinya penelitian tersebut hanya dilakukan pada satu sasaran (satu lokasi atau satu objek).

Peneliti menggunakan metodologi penelitian kualitatif yang bersifat deskriptif dimana data yang dikumpulkan terutama berupa kata-kata dan kalimat, atau gambar yang memiliki arti lebih dari sekedar angka atau frekuensi. Penelitian ini dikategorikan dalam penelitian deskriptif kualitatif. Penelitian ini dilakukan untuk mendapatkan analisis yang cermat terhadap suatu fenomena sosial tertentu. Penelitian mengembangkan konsep dan penghimpunan fakta, tetapi tidak melakukan pengujian hipotesa.

Dalam penelitian ini, peneliti memilih jenis penelitian kualitatif yang bersifat deskriptif karena peneliti hanya ingin memaparkan situasi dan peristiwa, mendeskripsikan secara rinci dan mendalam mengenai kondisi yang sebenarnya terjadi menurut kondisi nyata di lapangan, dalam hal ini adalah tentang kecepatan, ketepatan dan efisiensi informasi Al Firdaus. Peneliti tidak mencari atau menjelaskan hubungan serta tidak menguji hipotesis atau membuat prediksi. 
https://ejurnal.stimi-bjm.ac.id/index.php/JR/MK

\section{HASIL PENELITIAN DAN PEMBAHASAN}

Berikut akan dikemukakan hasil temuan di lapangan yang diperoleh mengenai sampel penelitian yang meliputi : waktu penggunaan $e$ commerce, pengikut (follower), wilayah penjualan, sumber daya yang harus dipersiapkan, biaya yang dikeluarkan, hambatan atau kendala, dan omset.

1. Waktu Penggunaan E-commerce

Tahun dimulainya penggunaan e-commerce dengan akun Instragram: @ pengrajinanyamanpurunalfirdaus sejak tahun 2017 dengan pengikut (follower) sampai saat ini sebanyak 798 orang.

2. Wilayah Penjualan

Ditinjau dari wilayah penjualan atau pasar yang dituju perusahaan dapat diketahui bahwa pemasaran sebelumnya hanya bersifat lokal menunggu pelanggan datang ke rumah dan hanya di sekitaran Kota Banjarbaru. Dan saat ini sudah banyak pelanggan yang berasal dari luar kota Banjarbaru hingga ke luar provinsi.

3. Sumber Daya yang Disiapkan

Sumber daya yang dimiliki toko Al Firdaus ini antara lain administrator akun, aplikasi Instagram yang telah ada di telepon seluler, dan paket data internet. Kemudian biaya yang dikeluarkan hanya untuk pembelian paket data internet yang masih terjangkau.

4. Hambatan/Kendala

Ditemukan hambatan/kendala dalam penerapan e-commerce melalui Instagram ini, yaitu:

a. Koneksi jaringan internet di daerah Kelurahan Palam kurang bagus, sehingga mengakibatkan akses Instagram menjadi lambat.

b. Masih belum menguasai desain grafis sehingga media promosi kurang menarik.

5. Omset

Omset yang dimaksud dalam penelitian ini adalah omset penjualan yang berhasil diperoleh perusahaan per bulan sebelum dan sesudah menerapkan e-commerce. Hal ini dimungkinkan karena omset penjualan adalah data pribadi dari perusahaan itu sendiri dan untuk dikonsumsi dari kalangan internal sehingga dilakukan secara langsung melalui wawancara dengan pemilik $\mathrm{Al}$ Firdaus, Mufidah.

Tabel 1. Data Pengikut Instagram dan Hasil Penjualan Sebelum dan Sesudah menggunakan Instagram

\begin{tabular}{ccccc}
\hline Tahun & 2016 & 2017 & 2018 & 2019 \\
\hline Status & Offline & Online & Online & Online \\
\hline
\end{tabular}

\begin{tabular}{lcccc}
\hline $\begin{array}{l}\text { Pengikut } \\
(\text { Follower })\end{array}$ & 0 & 136 & 451 & 798 \\
\hline $\begin{array}{l}\text { Rata-Rata } \\
\text { Omset/Bln }\end{array}$ & 500.000 & 750.000 & 1.500 .000 & 3.000 .000 \\
\hline Persentase & $0 \%$ & $50 \%$ & $300 \%$ & $600 \%$ \\
\hline
\end{tabular}

Pada Tabel 1, dapat dilihat data pengikut terus meningkat setiap tahun dan hasil penjualan sebelum dipasarkan secara online rata-rata Rp500.000 perbulan, dan sesudah menggunakan Instragram dari 2017-2019 meningkat hingga ratarata $\mathrm{Rp} 3.000 .000$.

\section{Pembahasan}

Menurut Utami dan Purnama (2012) dalam komunikasi pemasaran, penyampaian informasi menjadi aktivitas paling penting. Informasi dalam komunikasi disebut juga sebagai pesan (message), dalam menyampaikan pesan, pemasar harus memperhatikan beberapa hal sebagai berikut:

\section{Pola Pesan}

Menurut Machfoedz (2010), bagian terpenting dari strategi penyampaian pesan pemasaran adalah penetapan cara terbaik untuk mengkomunikasikan pokok pesan kepada khalayak sasaran dalam hal ini adalah konsumen/pelanggan. Ada 2 faktor yang perlu diperhatikan dalam penyampaian pesan (presentasi), yaitu: isi pesan harus berorientasi pada produk dan tingkat kepedulian konsumen harus terbangun. Hal ini dapat dilakukan dengan cara sebagai berikut:

- Menyampaikan informasi yang sebenarnya tentang produk yang dijual, dapat dilihat pada Gambar 2.

- Memberikan gambar-gambar produk dengan rancangan desain terbaru yang inovatif, dan menarik konsumen, dapat dilihat pada Gambar 3.

- Menjawab pertanyaan-pertanyaan konsumen tentang produk secara detail.

- Menyakinkan konsumen bahwa Al Firdaus dapat dipercaya dengan memberikan nomor kontak dan email maupun alamat untuk kemudahan komunikasi.

- Jaminan barang rusak pada saat pengiriman akan diganti dengan barang yang baru dengan model dan motif yang sama tanpa dibebankan biaya pengiriman.

- Barang sesuai dengan yang tertera di tampilan Instagram. 


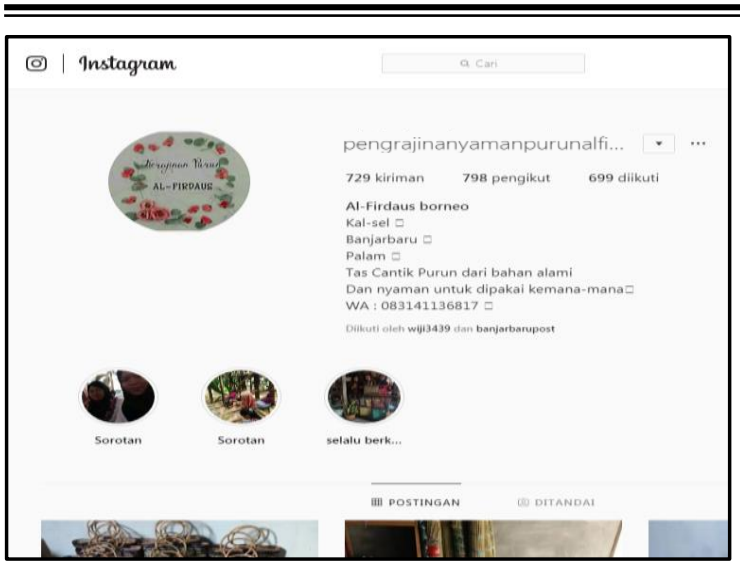

Gambar 2. Informasi profil Al Firdaus

\section{Media Penyampaian}

Instagram memiliki beberapa fasilitas untuk menyampaikan pesan kepada membernya, dapat melalui inbox (kotak pesan), posting status, catatan dan image tagging. Al Firdaus menggunakan fasilitas-fasilitas ini secara berkala dan terencana, misal dengan cara:

- 3 hari sekali mengirimkan informasi produk melalui inbox maupun email.

- 1 minggu sekali membuat catatan terkait dengan keunggulan produk.

- 2 minggu sekali menghasilkan produk-produk terbaru sehingga customer selalu mengupdate atau Melakukan inovasi produk sehingga customer tidak merasa bosan dengan model yang sama.

- Selalu membuka inbox bagi customer yang hendak bertanya tentang produk Al Firdaus.

- Cantumkan ukuran dan harga serta material.

\section{Mengatur Penyampaian Pesan}

Mengatur frekuensi penyampaian pesan melalui media yang disediakan oleh Instagram memang harus secara berkala dan terencana, adapun cara-caranya adalah sebagai berikut:

- Menyampaikan Judul atau Subyek pesan yang menarik.

- Mengirim pesan secara personal kepada customer, bukan massal agar tidak dianggap sebagai spam.

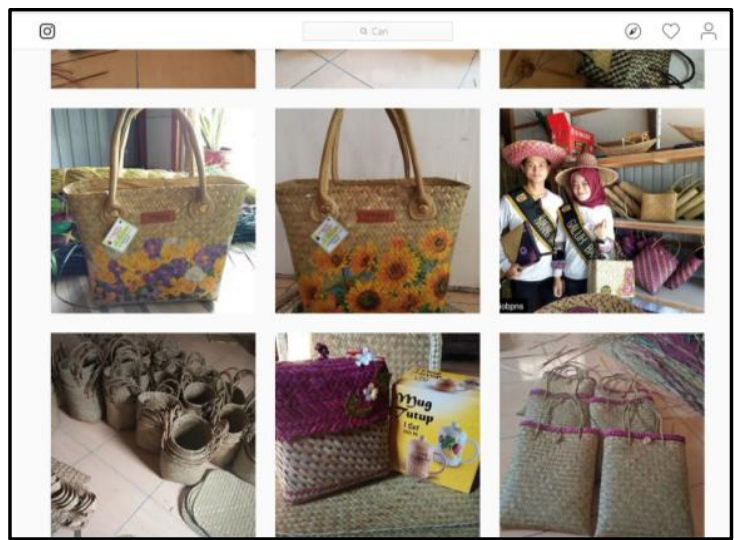

Gambar 3. Tampilan produk di akun

@ pengrajinanyamanpurunalfirdaus

- Membuat pesan sesingkat dan sejelas mungkin.

- $\quad$ Selalu akhiri dengan kontak.

- Membuat jadwal dan frekuensi pengiriman pesan secara berkala.

- Mengunggah testimoni pelanggan yang telah memesan produk di @pengrajinanyamanpurunalfirdaus sebagai bentuk kepercayaan pelanggan.

- Berikan feedback secepat mungkin sehingga pelanggan merasa dilayani dengan baik.

\section{Merancang Promosi}

Promosi dilakukan untuk berkomunikasi dan mempengaruhi pelanggan agar dapat menerima produk yang dihasilkan. Pemasar dapat merancang promosi dengan berbagai cara, seperti periklanan, promosi penjualan, publisitas penjualan individu dan kemasan yang menarik (Utami dan Purnama, 2012). Al Firdaus melakukan promosi melalui beberapa cara diantaranya:

\section{Periklanan}

Menyampaikan pesan kepada konsumen berupa informasi produk, dalam bentuk gambar maupun deskripsi produk.

\section{Publisitas Penjualan Individu}

Publisitas Penjualan Individu atau Personal Selling adalah menjual secara langsung kepada masingmasing konsumen, ini dapat dilakukan dengan cara berkomunikasi langsung dengan konsumen, baik dengan cara mengirim pesan atau dengan melakukan obrolan.

Berdasarkan pembahasan ini ditemukan bahwa pemanfaatan media sosial Instagram mempunyai dampak positif bagi pengembangan pemasaran produk Al Firdaus sehingga pengikut Instagram dan penjualan meningkat. Selain itu juga, pengoperasiannya yang mudah dan banyak penggunanya sehingga menjadi media promosi praktis, yang murah, handal dan dapat menjangkau 
seluruh pengguna di mana saja berada. Namun demikian, masih ada beberapa kendala dan kelemahan yang ditemui yaitu akses internet yang kurang baik di wilayah Palam, kurangnya keahlian pemilik toko dalam membuat desain yang bagus dan menarik, serta tidak dimunculkan harga produk sehingga harus berkomunikasi melalui kontak yang disediakan.

\section{PENUTUP}

Berdasarkan hasil penelitian yang telah dilakukan maka peneliti, maka dapat ditarik kesimpulan :

1. Peran Instagram sangat besar dalam proses pemasaran yang dilakukan melalui akun alfirdausborneo. Tidak hanya sebagai media atau saluran, namun juga merupakan penggerak dalam setiap tahap proses pemasaran. Mulai dari penyampaian pesan melalui posting-an gambar produk, proses penerimaan dan pengelelolaan tanggapan (respon) dari pelanggan, hingga kepada penerimaan umpan balik (feedback) dari pelanggan.

2. Instagram sangat membantu proses pemasaran yang dilakukan Al Firdaus, dengan segala fiturfitur yang dimiliki sangat mudah untuk digunakan dan membantu proses pemasaran pada produk walaupun tidak semua fitur digunakan Mufidah dalam proses pemasaran.

3. Peran Instagram pada bisnis online Al Firdaus terbilang sukses terlihat dengan pencapaian jumlah followers pada akun Instagram @ pengrajinanyamanpurunalfirdaus_yang mencapai 798 dan followers tersebut adalah sejak tahun 2017, kemudian dari segi produksi dan penghasilan yang didapat oleh Al Firdaus $600 \%$, juga banyaknya feedback yang diterima dari pelanggan Al Firdaus dari dalam dan luar kota Banjarbaru.

4. Kendala yang ditemui seperti sulitnya akses internet, kurangnya keahlian dalam menguasai desain grafis dan kurangnya deskripsi produk, seperti harga yang tidak tercantum.

\section{Rekomendasi}

Hasil penelitian ini merekomendasikan agar Pemilik Toko Pengrajin Anyaman Purun meningkatkan kemampuan desain grafis secara maksimal untuk mendapatkan desain tampilan Instagram yang bagus dan menarik, baik dengan belajar sendiri, melihat akun lain dan/atau mengikut pelatihan/kursus. Selain itu juga membuat deskripsi produk yang lebih baik dan lengkap, seperti pencantuman harga.

Bagi pihak-pihak terkait, terutama Pemerintah Kota Banjarbaru supaya lebih mendukung fasilitas teknologi yaitu akses internet agar masyarakat (pelaku UMKM) tidak lagi mengalami kendala kesulitan akses internet.

Bagi penelitian selanjutnya direkomendasikan untuk melakukan penelitian yang terkait dengan jumlah responden atau sampel yang lebih banyak, sehingga akan dapat ditemukan permasalahan dan manfaat yang lebih besar.

\section{DAFTAR PUSTAKA}

Afriani, U.F. (2012). Strategi Komunikasi Pemasaran Rown Division dalam Memanfaatkan Media Jejaring Sosial Facebook Sebagai Sarana Promosi Secara Online. Skripsi. Solo: Universitas Muhammadiyah Surakarta.

Agatha, K.S. (2015). Peranan Instagram Sebagai Media Komunikasi Pemasaran Bisnis Online (Studi Deskriptif Kualitatif pada Bisnis Online Floshablee). Skripsi. Medan: Universitas Sumatera Utara.

Aliansyah, M. Rifqi \& Ali, Dini S.F.A. (2017). Strategi Komunikasi Pemasaran Melalui Media Instagram (Studi Kasus Forever Young Crew). E-Proceeding og Management, 4(3), 2123-3128.

Amelia, L.S. \& Robahi, L. (2007). Penerapan Ecommerce Sebagai Upaya Meningkatkan Persaingan Bisnis Perusahaan. Artikel Penelitian. Surabaya: STIE Perbanas.

Banjaransari, Y.G. 2018. Pemanfaatan Instagram sebagai Media Komunikasi Pemasaran Online Page Down Cloth Maker. Skripsi. Solo: Universitas Muhammadiyah Surakarta.

Carlson, Steve. (2010). Fuzzy Sets and Fuzzy Topologies: Early Ideas and Obstacles. New York: Rose-Hulman Institue of Technology.

Kusuma, D. F. \& Sugandi, M. S. (2018). Strategi Pemanfaatan Instagram Sebagai Media Komunikasi Pemasaran Digital yang Dilakukan oleh Dino Donuts. Jurnal Manajemen Komunikasi, 3(1) 8-33.

Febiningrum, E. K. (2015). Implementasi dari Penerapan Sistem Informasi Manajemen di Perusahaan PT Indofood Sukses Makmur, Tbk. Semarang: STIE Bank BPD Jateng.

Gumilar, Gumgum. (2015). Pemanfaatan Instagram sebagai Sarana Promosi oleh Pengelola Industri Kreatif Fashion di Kota Bandung. Jurnal Ilmu Politik dan Komunikasi, V(2), 7784.

Irma, Ade. (2017). Peran Instagram Sebagai Media Komunikasi Pemasaran Bisnis Online (Studi Deskriptif Kualitatif pada Bisnis Online Beautyhomeshop). Jurnal Online Kinesik, 4(2), 1-12. 
Kotler, Philip. (2001). Manajemen Pemasaran: Analisis, Perencanaan, Implementasi dan Kontrol. Jakarta: PT Prehallindo.

Machfoedz, Mahmud. (2010). Komunikasi Pemasaran Modern. Cetakan Pertama. Yogyakarta: Cakra Ilmu.

Maryama, Siti. (2013). Penerapan E-Commerce dalam Meningkatkan Daya Saing Usaha. Jurnal Liquidity, 2(1), 73-79.

Morissan. (2010). Periklanan Komunikasi Pemasaran Terpadu. Jakarta: Kencana Prenadamedia Group.

Nurlita, Rizqi. (2018). Pemanfaatan Instagram sebagai Media Pemasaran Online pada Matakuliah Kewirausahaan (Study Kasus pada Jurusan Pendidikan IPS FITK UIN Maulana Malik Ibrahim Malang). Skripsi. Malang: Universitas Islam Negeri Maulana Malik Ibrahim.

O’Brien, James A dan Marakas, George M. (2008). Management Information System. Boston: McGraw-Hill.

Rahmawati, Dewi. (2016). Pemilihan dan Pemanfaatan Instagram Sebagai Media Komunikasi Pemasaran Online (Studi Desktiptif Kualitatif pada Akun Instagram @FreezyBrowniezz. Skripsi. Yogyakarta: Fakultas Ilmu Sosisal dan Humaniora Universitas Islam Negeri Sunan Kalijaga.

Rakhmat, Jalaludin. (2000). Metode Penelitian Komunikasi. Bandung: PT Remaja Rosdakarya.

Ramadhan, Fadli H. (2017). Pemanfaatan Media Sosial Instagram Akun@Al Firdaus Sebagai Promosi dalam Meningkatkan Penjualan. JOM FISIP, 4(2), 1-15.

Reza, Faisal. (2016). Strategi Promosi Penjualan Online Lazada.co.id. Jurnal Kajian Komunikasi, 4(1) 64-74.

Sarastuti, Dian. (2017). Strategi Komunikasi Pemasaran Online Produk Busana Muslim Queenova. Jurnal Visi Komunikasi, 16(1), 7190.

Sudirwo. (2020). The Implementation of the SOEs Partnership Program on the empowerment of MSMEs in Banjarbaru City. Jurnal Ilmiah Ekonomi Bisnis, 6(1), 61-73.

Suyanto, M. (2003). Strategi Periklanan pada ECommerce Perusahaan Top Dunia. Yogyakarta: Andi Offset.

Utami, A.D., \& Purnama, B.E. (2012). Pemanfaatan Jejaring Sosial (Facebook) sebagai Media Bisnis Online (Studi Kasus di Batik Solo 85). Seruni FTI UNSA, 1, 1-7.

https://id.wikipedia.org/wiki/Purun diakses $10 \mathrm{Juli}$

\section{Profil Penulis}

1. Sudirwo, S.E., M.M., Keilmuan Manajemen, Sekolah Tinggi Ilmu Ekonomi (STIE) Pancasetia Banjarmasin, Jalan A. Yani KM 5,7 Banjarmasin - 70248 Email: sudirwo@gmail.com

2. Hj. Arifia Nurriqli, S.E., M.M., Keilmuan Manajemen, Sekolah Tinggi Ilmu Ekonomi (STIE) Pancasetia Banjarmasin.

3. Muhammad Risanta, S.E., M.M., Keilmuan Manajemen, Sekolah Tinggi Ilmu Ekonomi (STIE) Pancasetia Banjarmasin. 